Biological and Clinical Sciences Research Journal

ISSN: 2708-2261

www.bcsrj.com

DOI: https://doi.org/10.54112/bcsri.v2021i1.80

Biol. Clin. Sci. Res. J., Volume, 2020: 80

MEDEYE

Original Research Article

\title{
PHYTOCHEMICAL AND ANTIMICROBIAL ACTIVITY ANALYSIS OF SWERTIA CHIRAYITA AND ARTEMISIA ABSINTHIUM PLANT EXTRACTS
}

\author{
AFZAL $A^{1 *}$, AFTAB B ${ }^{1}$, SIDDIQUE $J^{1}$, BABAR $^{1}$, SOHAIL ${ }^{1}$, YASIR $M^{1}$, HANIF $S^{2}$ \\ ${ }^{1}$ Institute of Molecular Biology and Biotechnology, University of Lahore, Lahore, Pakistan \\ ${ }^{2}$ Emergency Department, Bahria Town International Hospital Lahore-Pakistan
}

*Corresponding author email: aminaafzal069@gmail.com

(Received, $16^{\text {th }}$ January 2021, Revised $21^{\text {th }}$ August 2021, Published $24^{\text {th }}$ August 2021)

\begin{abstract}
The Swertia chirayita and Artemisia absinthium (Afsanteen) plants extracts were evaluated for phytochemicals and their antimicrobial activity against 3 bacteria and 2 fungal strains by using the disc diffusion technique. Phytochemical analysis showed the presence of tannins, flavonoids, saponins, and terpenoids in Swertia chirayita while in Artemisia absinthium only saponins, terpenoids were present. To a very small extent tannins were present in the ethanolic extract of Afsanteen. But both plant extracts gave negative results for the presence of cardiac glycosides. Antibacterial activity of Swertia chirayita and Afsanteen plant extracts were screened against 3 bacterial strains (E. coli, Bacillus subtilis, Pseudomonas syringola) and 2 fungal strains (Aspergillus niger and Fusarium Solani). Ampicillin was used as a standard drug for antibacterial and antifungal activity. Results showed that Afsanteen and chirayita extracts showed activity against bacterial strains except for chirayita $n$-hexane and ethanol extract for Bacillus subtilis and Chirayita n-hexane extract for Pseudomonas syringola. A maximum zone of inhibition was noticed for chirayita ethanol extract against Pseudomonas syringola. But both plant extracts showed zero activity against fungal strains except Chirayita acetone extract against Fusarium solani while chirayita ethanol extract against Aspergillus niger. Both extracts of plants gave concentration-dependent activity. It was concluded that the presence of antimicrobial activity for both plant extracts indicated that is due to the presence of phytochemical compounds.
\end{abstract}

Keywords: antimicrobial, Swertia chirayita, Artemisia absinthium, ethanol, n-hexane, acetone, plant extract

\section{Introduction}

Swertia chirayita is a very famous herb which grows under temperate climatic condition of Himalaya. Family to which chirayita belongs is Gentianaceae. chirayita is also called Indian gentian (Joshi et al., 2005; Aleem et al., 2018). Gentianaceae is a flowering family which contains a range of floral patterns and colors. Swertia chirayita is annual or biennial herb of seasonal growth. The size of chirayita stems range from $60 \mathrm{~cm}$ to $150 \mathrm{~cm}$. Stems are cylindrical at the base and upwardly quadrangular (Khanal et al., 2014). Color of stems is greenish brown at the young age of plant and this color changes from light brown to violet when plant at its maturity stage. Its leaves are $10 \mathrm{~cm}$ long that are in opposite in pair pointed at tips without stalks (Keshebo et al., 2016; Ahirwal et al., 2010). Cross pollination in $S$. chirayita is promoted due to the presence of nectaries and multi colored corolla (Kumar and Sharma, 2015). S. Chirayita flourishes as well as thrives in woodland gardens having partial shade sunny edge as well as in marshy lands.
Chirayita plant is very famous because of its therapeutic uses (Kaloo and Bhat, 2020), due to the presence of different chemical compounds like Triterpenoids, Mangiferin, Swerchirin, flavonoids, terpenoids, saponins, Lignans, Pentacyclic Triterpenoids etc (Khalid et al., 2011).

Afsanteen is a perennial plant belongs to family Asteraceae or Compositae. Its scientific name is Artemisia absinthium and called Afsanteen in Unani system of medicine. Dried leaves, herb and flowering tops are used in Unani system of medicine. This herb also used in preparation of decoction, sharbat and arq (Ansari et al., 2019). Artemisia absinthium have fibrous roots and it is woody based perennial herbaceous plant. The leaves of Afsanteen plant are spirally arranged, greenish gray above and below portion are white, covered with silky silvery- white trichomes, bipinnate and tripinnate with long petioles (Erdigrul, 2002; Hashimi 2019). The flowers of this plant are pale yellow, tubular, have ornamental value, clustered in spherical capitula. Flowering occurs from

[Citation: Afzal, A., Aftab, B., Siddique, J., Babar, S., Sohail, A., Hanif, M., Hanif, S. (2021). Phytochemical and antimicrobial activity analysis of Swerita charyita and Artemisis absinthium plant extracts. Biol. Clin. Sci. Res. J., 2021: 80. doi: https://doi.org/10.54112/bcsrj.v2021i1.80] 
early summer to early autumn (Hashimi et al., 2019). This plant is native to temperate regions of Northern United States, Northern Africa, Kashmir, Nepal, Afghanistan, US, Canada, westward to the Atlantic, the Midwest, the Great Plains and Eurasia. This plant is aromatically tonic and enjoyed a higher reputation in debility of digestive organs. This herb also regarded as Anthelmintics or antihelminthics (Ashraf et al., 2019). Afsanteen grows in dry waste places in Europe like roadsides (Beigh and Ganai, 2017). Artemisia absinthium contains many compounds which are responsible for its bioactivity like hujyl alcohol esters, $\alpha$-cadinene, guaiazuleneepoxyocimene, sabinyl acetate, (Z) - chrysantenyl acetate. Other important compounds of Afsanteen are bitter sesquiterpenoid lactones, absinthin. Bitter compounds that are obtained from this herb are artamaridin, artamarin, artamaridinin, artamarin. This herb also has many flavonoids (Goud and Swamy, 2015; Szopa et al., 2020).

The present investigation was undertaken to study the antimicrobial activity of crude extracts of Swertia chirayita and Artemisia absinthium whole plants in different solvents against bacterial and fungal strains.

\section{Materials and Methods}

\section{Plant material}

Artemisia absinthium (Afsanteen) plant and Swertia Chirayita plant samples were collected from local market of Lahore. The samples were air dried separately after light washing in water (to clean dust and other particles) and after about 5-7 days when these herbs dried properly they were grinded to obtain their powdered form.

\section{Extracts of whole plant materials}

Ethanol, n-hexane and acetone extracts of chirayita and Afsanteen plants were prepared by soaking $15 \mathrm{~g}$ of each of the dry powdered plant material separately in $150 \mathrm{ml}$ of ethanol-hexane and acetone at room temperature for 2 days. After 2 days these extracts were filtered through filter paper. The extracts were concentrated by using rotary evaporator with water bath at $40^{\circ} \mathrm{C}$ or also evaporated by opening the lid of reagent bottles for 1-2 days in which filtered plant solution are present. Then these extracts were stored separately in $1.5 \mathrm{ml}$ micro centrifuge tubes by proper labeling of each plant name and solution names (nhexane, acetone, and ethanol).

\section{Phytochemical screening}

Qualitative chemical tests were performed for each extract of Afsanteen and chirayita plants by using standard procedures.

\section{Test for terpenoids}

$0.5 \mathrm{~g}$ ethanolic extract of Afsanteen was added to $2 \mathrm{ml}$ of chloroform and then $3 \mathrm{ml}$ sulphuric acid in concentrated form was added carefully to form a layer. Reddish brown color at interface shows the presence of terpenoid. Perform this test for each extracted sample material in same way.

\section{Test for flavonoids}

$5 \mathrm{ml}$ of dilute ammonia was added to a portion of filtered extract of each of plant material separately, and then $1 \mathrm{ml}$ of concentrated sulphuric acid was added. Yellow color was disappeared while standing indicated the presence of flavonoids.

\section{Test for tannins}

$0.5 \mathrm{~g}$ of each extract was boiled separately in $10 \mathrm{ml}$ of distilled water in a test tube and then each solution was filtered. Few drops of ferric chloride $(0.1 \%)$ was added to the filtrate separately. Blue-black or brownish green color shows the presence of tannins.

\section{Test for saponins}

$0.5 \mathrm{~g}$ of each extract was added to $5 \mathrm{ml}$ of distilled water in test tube. Vigorously the solution was shaken and stable persistent froth formation was observed. Then 3 drops of olive oil were mixed to the froth in each test tube and then each test tube was observed for an emulsion formation.

\section{Keller-Killiani test (cardiac glycosides test)}

$5 \mathrm{ml}$ of distilled water was added to $0.5 \mathrm{~g}$ of extract that was in test tubes separately. Then $2 \mathrm{ml}$ of glacial acetic acid and 1 drop of ferric chloride solution. $1 \mathrm{ml}$ of sulphuric acid was added Afsanteen acetone. At the interface Brown ring shows the presence of deoxy-sugar characteristic of cardenolides. Below brown ring violet ring appears and in acetic acid layer green ring forms above brown ring and slowly spread throughout the layer.

\section{Antibacterial Activity \\ Media preparation}

$12 \mathrm{~g}$ of nutrient agar powder was added in $500 \mathrm{ml}$ of water and after dissolving completely it was autoclaved at $121^{\circ} \mathrm{C}$ for $15 \mathrm{~min}$. After autoclaving media was poured in 18 petri plates for checking antibacterial activity of plant extracts.

\section{Antibacterial assay}

After complete solidification of media isolated bacterial samples (E. coli, Pseudomonas syringola, and Bacillus subtiis) were streaked separately on each plate properly. Then ampicillin disc placed on plate and 3 simple discs were also placed on same plate, each plate is labeled properly where the control disc (antibiotic disc) on plate is and where are simple plates. $5 \mu 1,10 \mu 1$ and $15 \mu 1$ of each plant extracts were poured separately on simple discs such as $5 \mu$ l ethanol extract of chirayita on one simple disc and $10 \mu 1$ ethanol extract on $2^{\text {nd }}$ simple disc and $15 \mu 1$ ethanol extract of chiriata on $3^{\text {rd }}$ disc. Same concentrations of plant extracts were used for each plate. Then plates were incubated overnight at $37^{\circ} \mathrm{C}$. After incubation period plates were observed for clear zone formation

[Citation: Afzal, A., Aftab, B., Siddique, J., Babar, S., Sohail, A., Hanif, M., Hanif, S. (2021). Phytochemical and antimicrobial activity analysis of Swerita charyita and Artemisis absinthium plant extracts. Biol. Clin. Sci. Res. J., 2021: 80. doi: https://doi.org/10.54112/bcsrj.v2021i1.80] 
around the simple discs which corresponds to antimicrobial activity of tested compounds. At last zone of inhibition was measured in $\mathrm{mm}$ for each plate.

\section{Antifungal activity \\ Media preparation}

$17 \mathrm{~g}$ of LB agar was dissolved completely in $500 \mathrm{ml}$ water and then autoclaved at $121^{\circ} \mathrm{C}$ for $15 \mathrm{~min}$. Then autoclaved media was poured in 12 petri plates and placed for solidification of media.

\section{Antifungal assay}

Fusarium solani and A. Niger isolated fungal samples were streaked properly. First fungal sample was streaked in solidified 6 petri plates and similarly $2^{\text {nd }}$ fungal sample was also streaked in remaining 6 plates sterilized loop. Then ampicillin disc placed on plate and 3 simple discs were also placed on same plate, each plate is labeled properly where the control disc (antibiotic disc) on plate is and where are simple plates. $5 \mu 1,10 \mu 1$ and $15 \mu 1$ of each plant extracts were poured separately on simple discs such as $5 \mu 1$ ethanol extract of chirayita on one simple disc and $10 \mu \mathrm{l}$ ethanol extract on $2^{\text {nd }}$ simple disc and $15 \mu$ l ethanol extract of chirayita on $3^{\text {rd }}$ disc. Same concentrations of plant extracts were used for each plate. Then plates were incubated for $2-3$ days at $37^{\circ} \mathrm{C}$. After incubation period plates were observed for clear zone formation around the simple discs which corresponds to antimicrobial activity of tested compounds. At last zone of inhibition was measured in $\mathrm{mm}$ for each plate. All of above described procedure was performed in biosafety cabinet.

\section{Results and discussions}

In this study phytochemical compounds of chirayita and Afsanteen plant and their antimicrobial activity were recorded. Results of the study are given below:

\section{Terpenoid Test}

In this test it was found that in chirayita (ethanol extract-hexane and acetone extract) and Afsanteen (acetone, ethanol and n-hexane extract) terpenoid are present because reddish brown coloration at the interface was observed (Table 1). The presence of terpenoids revealed the potential of extracts as antioxidants and pharmacological uses. The plants chirayita and Afsanteen may be used as potential medicinal plants (Aleem and Kabir, 2018; Parmar et al., 2012).

\section{Flavonoids Test}

It was found that in chirayita (ethanol, n-hexane and acetone extracts) flavonoid is present which was confirmed experimentally because a yellow color was appeared and that color disappears on standing which indicates the presence of flavonoids. But in Afsanteen flavonoids were not present because no change in color was observed when this test was performed (Table 1). The presence of flavonoids revealed the potential of extracts as antioxidants and pharmacological uses. The plants chirayita and Afsanteen may be used as potential medicinal plants (Aleem and Kabir, 2018; Bhargava et al., 2009; Kaloo and Bhat, 2020; Parmar et al., 2012; Rafe, 2017).

\section{Tannins Test}

If brownish green or blue black color appears it means tannins are present. Here it was observed that ethanolic chirayita extract have tannins and in remaining extracts except Afsanteen (n-hexane and acetone extracts) tannins may be present to some extent (Table 1). The presence of tannins revealed the potential of extracts as antioxidants, anticancer and pharmacological uses. The plants chirayita and Afsanteen may be used as potential medicinal plants (Hashimi et al., 2019; Ashraf et al., 2019; Szopa et al., 2020).

\section{Saponins Test}

Emulsion formation indicates their presence. So it was found that saponins are present in chirayita (ethanol extract, acetone extract) Afsanteen (nhexane extract and acetone extract) because they form an emulsion but in chirayita n- hexane and in Afsanteen ethanol saponins are not present because no emulsion was observed (Table 1). The presence of saponins revealed the potential of extracts as antioxidants, anticancer, anti-inflammatory and pharmacological uses (Ansari et al., 2019; Ashraf et al., 2019; Das et al., 2012; Szopa et al., 2020).

\section{Keller-Killiani test results}

This test showed negative results in Afsanteen and chirayita extracts.

\section{Antibacterial assay results}

Anti-microbial activity evaluation of selected plant extracts was determined initially by disc diffusion method against different bacterial strains. The study revealed that all plant extracts used in research work have a varying degree of antimicrobial activity against used bacterial strains that were used that is explained in given table 2. It was observed that chirayita is most effective against $E$. coli as compared to Afsanteen. In case of subtilis Afsanteen was found to be effective as compared to chirayita . In case of $P$. syringola Afsanteen and chirayita showed antibacterial property except chirayita nhexane extract. The presence of antibacterial activities revealed the potential of extracts as antibiotics. The plants chirayita and Afsanteen may be used as potential medicinal plants (Kumar and Van Staden, 2016; Ahirwal et al., 2010; Ashraf et al., 2019; Medda et al., 1999).

[Citation: Afzal, A., Aftab, B., Siddique, J., Babar, S., Sohail, A., Hanif, M., Hanif, S. (2021). Phytochemical and antimicrobial activity analysis of Swerita charyita and Artemisis absinthium plant extracts. Biol. Clin. Sci. Res. J., 2021: 80. doi: https://doi.org/10.54112/bcsrj.v2021i1.80] 


\section{Antifungal assay results}

Anti-microbial activity evaluation of different plant extracts was determined initially by disc diffusion method against different fungal strains (Aspergillus niger, Fusarium solani).It was found that only chirayita acetone extract showed antifungal activity to some extent and remaining all the extracts there were used showed that they have no antifungal activity (Table 3 ).

Table1. Shows results of Phytochemical screening test

\begin{tabular}{|c|c|c|c|c|c|}
\hline Plant extracts & $\begin{array}{l}\text { Terpenoid } \\
\text { Test }\end{array}$ & $\begin{array}{l}\text { Flavonoids } \\
\text { Test }\end{array}$ & Tannins Test & $\begin{array}{l}\text { Saponins } \\
\text { Test }\end{array}$ & $\begin{array}{l}\text { Keller- } \\
\text { Killiani test }\end{array}$ \\
\hline Chirayita Ethanol extract & $+\mathrm{ve}$ & $+\mathrm{ve}$ & $+\mathrm{ve}$ & $+\mathrm{ve}$ & -ve \\
\hline Chirayita n-hexane extract & + ve & $+\mathrm{ve}$ & $\begin{array}{l}\text { +ve to some } \\
\text { extent }\end{array}$ & -ve & -ve \\
\hline Chirayita Acetone extract & $\begin{array}{l}\text { +ve to some } \\
\text { extent }\end{array}$ & $+\mathrm{ve}$ & $\begin{array}{l}\text { +ve to some } \\
\text { extent }\end{array}$ & $+\mathrm{ve}$ & -ve \\
\hline Afsanteen ethanol extract & $+\mathrm{ve}$ & -ve & $\begin{array}{l}\text { +ve to some } \\
\text { extent }\end{array}$ & -ve & -ve \\
\hline Afsanteen $n$-hexane extract & $+\mathrm{ve}$ & -ve & -ve & $+\mathrm{ve}$ & -ve \\
\hline Afsanteen acetone extract & $+\mathrm{ve}$ & -ve & -ve & $+\mathrm{ve}$ & -ve \\
\hline
\end{tabular}

Antibacterial assay result

Table 2. Diameter of zones of inhibition ( $\mathrm{mm}$ ) of plant extracts against E. coli, B. subtilis and P. syringola at $5 \mu 1$, $10 \mu \mathrm{l}$ and $15 \mu \mathrm{l}$ concentrations with control antibiotic disc of Ampicillin

\begin{tabular}{|c|c|c|c|c|}
\hline $\begin{array}{l}\text { Bacterial } \\
\text { Names }\end{array}$ & Plant extracts & $\begin{array}{l}\text { Concentration } \\
\text { extract }(5 \mu \mathrm{L})\end{array}$ & $\begin{array}{r}\text { of Concentration } \\
\text { extract }(10 \mu \mathrm{L})\end{array}$ & $\begin{array}{r}\text { of Concentration } \\
\text { extract }(15 \mu L)\end{array}$ \\
\hline E. coli & Afsanteen(ethanol) & 1.65 & 1.57 & 1.55 \\
\hline E. coli & Afsanteen(acetone) & 1 & 0.8 & 1 \\
\hline E. coli & Afsanteen(n-hexane) & 0.6 & 0.8 & 0.75 \\
\hline E. coli & Chirayita (ethanol) & 1 & 1.25 & 1.2 \\
\hline E. coli & Chirayita (n-hexane) & 1.25 & 1.6 & 1.8 \\
\hline E. coli & Chirayita (acetone) & 1.95 & 1.75 & 1.9 \\
\hline B. Subtilis & Afsanteen(acetone) & 1 & 1.5 & 1.1 \\
\hline B. Subtilis & Afsanteen(n-hexane) & 1 & 1 & 1 \\
\hline B. Subtilis & Afsanteen(ethanol) & 0.4 & 0.4 & 0.5 \\
\hline B. Subtilis & Chirayita (n-hexane) & 0 & 0 & 0 \\
\hline B. Subtilis & Chirayita (ethanol) & 0 & 0 & 0 \\
\hline B. Subtilis & Chirayita (acetone) & 0.9 & 1 & 1 \\
\hline P. Syringola & Afsanteen(acetone) & 1.8 & 1.5 & 2 \\
\hline P. Syringola & Afsanteen(n-hexane) & 0.9 & 0.6 & 1 \\
\hline P. Syringola & Afsanteen(ethanol) & 1.1 & 1.6 & 1.7 \\
\hline P. Syringola & Chirayita (n-hexane) & 0 & 0 & 0 \\
\hline P. Syringola & Chirayita (ethanol) & 2 & 2 & 1.8 \\
\hline P. Syringola & Chirayita (acetone) & 1.5 & 1 & 1.4 \\
\hline
\end{tabular}

Antifungal assay results

Table 3. Diameter of zones of inhibition (mm) of plant extracts against Aspergillus Niger, Fusarium Solani at 5 $\mu 1$, $10 \mu 1$ and $15 \mu l$ concentrations

\begin{tabular}{llllll}
\hline Fungal strains & Plant extracts & $\begin{array}{l}\text { Concentration } \\
\text { extract }(\mathbf{5} \boldsymbol{\mu} \mathbf{L})\end{array}$ & $\begin{array}{l}\text { of } \\
\text { extract }(\mathbf{1 0 \mu} \mathbf{L})\end{array}$ & $\begin{array}{l}\text { of } \\
\text { extract }(\mathbf{1 5 \mu \mathbf { L } )}\end{array}$ \\
\hline A. Niger & Afsanteen (ethanol) & 0 & 0 & 0 \\
A. Niger & Afsanteen (acetone) & 0 & 0 & 0 \\
A. Niger & Afsanteen (n-hexane) & 0 & 0 & 0 \\
A. Niger & Chirayita (ethanol) & $1 \mathrm{~mm}$ & 0 & 0 \\
A. Niger & Chirayita (n-hexane) & $\begin{array}{l}\text { No growth occurs in } \\
\text { whole plate }\end{array}$ & $\begin{array}{l}\text { No growth occurs in } \\
\text { whole plate }\end{array}$ & $\begin{array}{l}\text { No growth occurs in } \\
\text { whole plate }\end{array}$ \\
A. Niger & Chirayita (acetone) & 0 & 0 & 1 \\
F. Solani & Afsanteen (ethanol) & 0 & 0 & 0 \\
\hline
\end{tabular}

[Citation: Afzal, A., Aftab, B., Siddique, J., Babar, S., Sohail, A., Hanif, M., Hanif, S. (2021). Phytochemical and antimicrobial activity analysis of Swerita charyita and Artemisis absinthium plant extracts. Biol. Clin. Sci. Res. J., 2021: 80. doi: https://doi.org/10.54112/bcsrj.v2021i1.80] 


\begin{tabular}{lllll}
\hline F. Solani & Afsanteen (acetone) & 0 & 0 & 0 \\
$F$. Solani & Afsanteen (n-hexane) & 0 & 0 & 0 \\
F. Solani & Chirayita (ethanol) & 0 & 0 & 0 \\
F. Solani & Chirayita (n-hexane) & 0 & 0 & 0 \\
F. Solani & Chirayita (acetone) & 1 & 1 & 1
\end{tabular}

\section{Conclusion}

Based on the results obtained in this study, it may be concluded that plant extracts of chirayita and Afsanteen have a stronger and broader spectrum of antimicrobial activity against number of bacteria's and plant extracts are used for discovering bioactive natural products that behave as a basic source for developing new antimicrobial compounds for overcoming the problem of increasing resistance to antibiotics that are available traditionally. Antibacterial activities could be increased if bioactive compounds are purified and proper dosage is determined. So, further studies can be performed for exploring Chirayita and Afsanteen potential for developing a number of drugs which will be effective with no side effects. But antifungal activity tests are not too much satisfied. So, detailed clinical research of Afsanteen and chirayita plant can be performed for its antifungal activity and exploring full therapeutic potential of these plants for the establishment of standard drug.

\section{Conflict of interest}

The authors declared absence of conflict of interest.

\section{References}

Ahirwal, L., Mehta, A., Mehta, P., John, J., \& Singh, S. (2010). Anthelmintic potential of Gymnema sylvestre and Swertia chirayita. Inventi Rapid: Ethnopharmacology, 2010.

Aleem, A., \& Kabir, H. (2018). Review on Swertia chirayita as traditional uses to its pyhtochemistry and phrmacological activity. Journal of Drug Delivery and Therapeutics, 8(5-s), 73-78.

Ansari, S., Shamshi, Y., \& Khan, Q. A. (2019). A review of Artemisia absinthium, Linn. (afsanteen) with special reference of Unani medicine. Journal of Pharmaceutical and Scientific Innovation, 8, 11-18.

Ashraf, S. S., Islam, N., Iqbal, A., Sheeraz, M., Quraishi, H. A., \& Rather, S. A. (2019). Artemisia absinthium linn (Afsanteen): a review. World Journal of Pharmaceutical Sciences, 8(1), 1421-1427.

Beigh, Y. A., \& Ganai, A. M. (2017). Potential of wormwood (Artemisia absinthium Linn.) herb for use as additive in livestock feeding: A review. The Pharma Innovation, 6(8, Part C), 176.
Das, S. C., Bhadra, S., Roy, S., Saha, S. K., Islam, M. S., \& Bachar, S. C. (2012). Analgesic and antiinflammatory activities of ethanolic root extract of Swertia chirayita (Gentianaceae). Jordan Journal of Biological Sciences, 5(1), 31-6.

Erdogrul, Ö. T. (2002). Antibacterial activities of some plant extracts used in folk medicine. Pharmaceutical Biology, 40(4), 269-273.

Goud, B. J., \& Swamy, B. C. (2015). A review on history, controversy, traditional use, ethnobotany, phytochemistry and pharmacology of Artemisia absinthium Linn. International Journal of Advanced Research in Engineering and Applied Sciences, 4(5), 77-107.

Hashimi, A., Siraj, M. B., Ahmed, Y., Siddiqui, M. A., \& Jahangir, U. (2019). One for AllArtemisia absinthium (Afsanteen). CELLMED, 9(4), 5-1.

Joshi, P., \& Dhawan, V. (2005). Swertia chirayita-an overview. Current science, 635-640.

Kaloo, M. A., \& Bhat, B. A. Chemical Composition and Pharmacology of a Medicinal Herb: Swertia Chirayita. International Pharmacology Science, 2020; 11: 105.

Keshebo, D. L., Washe, A. P., \& Alemu, F. (2016). Determination of antimicrobial and antioxidant activities of extracts from selected medicinal plants. American Scientific Research Journal for Engineering, Technology, and Sciences (ASRJETS), 16(1), 212-222.

Khalid, A., Rehman, U. U., Sethi, A., Khilji, S., Fatima, U., Khan, M. I., \& Murtaza, G. (2011). Antimicrobial activity analysis of extracts of Acacia modesta, Artimisia absinthium, Nigella sativa and Saussurea lappa against Gram positive and Gram negative microorganisms. African Journal of Biotechnology, 10(22), 4574-4580.

Khanal, S., Shakya, N., Nepal, N., \& Pant, D. (2014). Swertia chirayita: the himalayan herb. International Journal of Applied Sciences and Biotechnology, 2(4), 389-392.

Kumar, A., \& Sharma, S. (2015). Quantitative determination of swertiamarin, mangiferin and amarogentin in callus culture of Swertia chirayita by HPLC analysis. Journal of Pharmacology Research, 4, 1270-1279.

[Citation: Afzal, A., Aftab, B., Siddique, J., Babar, S., Sohail, A., Hanif, M., Hanif, S. (2021). Phytochemical and antimicrobial activity analysis of Swerita charyita and Artemisis absinthium plant extracts. Biol. Clin. Sci. Res. J., 2021: 80. doi: https://doi.org/10.54112/bcsrj.v2021i1.80] 
Kumar, V., \& Van Staden, J. (2016). A review of Swertia chirayita (Gentianaceae) as a traditional medicinal plant. Frontiers in Pharmacology, 6, 308.

Medda, S., Mukhopadhyay, S., \& Basu, M. K. (1999). Evaluation of the in-vivo activity and toxicity of amarogentin, an antileishmanial agent, in both liposomal and niosomal forms. Journal of Antimicrobial Chemotherapy, 44(6), 791-794.

Parmar, R. K., Kachchi, N. R., Tirgar, P. R., Desai, T. R., \& Bhalodiya, P. N. (2012). Preclinical evaluation of antiurolithiatic activity of Swertia chirayita stems. International Research Journal of Pharmacy, 3(8), 198-202.

Rafe, M. R. (2017). A review of five traditionally used anti-diabetic plants of Bangladesh and their pharmacological activities. Asian Pacific journal of Tropical Medicine, 10(10), 933-939.

Saha, P., \& Das, S. (2010). Highlighting the anticarcinogenic potential of an ayurvedic medicinal plant, Swertia Chirayita. Asian Pacific Journal of Cancer Prevention, 11(6), 1445-1449.

Szopa, A., Pajor, J., Klin, P., Rzepiela, A., Elansary, H. O., Al-Mana, F. A., \& Ekiert, H. (2020). Artemisia absinthium L. Importance in the History of Medicine, the Latest Advances in Phytochemistry and Therapeutical, Cosmetological and Culinary Uses. Plants, 9(9), 1063.

\section{(c) (1) 8}

Open Access This article is licensed under a Creative Commons Attribution 4.0 International License, which permits use, sharing, adaptation, distribution and reproduction in any medium or format, as long as you give appropriate credit to the original author(s) and the source, provide a link to the Creative Commons licence, and indicate if changes were made. The images or other third party material in this article are included in the article's Creative Commons licence, unless indicated otherwise in a credit line to the material. If material is not included in the article's Creative Commons licence and your intended use is not permitted by statutory regulation or exceeds the permitted use, you will need to obtain permission directly from the copyright holder. To view a copy of this licence, visit http://creativecommons.org/licen ses/by/4.0/.

(C) The Author(s) 2021

[Citation: Afzal, A., Aftab, B., Siddique, J., Babar, S., Sohail, A., Hanif, M., Hanif, S. (2021). Phytochemical and antimicrobial activity analysis of Swerita charyita and Artemisis absinthium plant extracts. Biol. Clin. Sci. Res. J., 2021: 80. doi: https://doi.org/10.54112/bcsrj.v2021i1.80] 